\title{
Screening and Characterization of Bacteriocin-Like Inhibitory Substances Produced by Bangladeshi Strains of Bacillus thuringiensis
}

\author{
Md. Nahidul Islam", Nahinur RahmanAkhand², Arafat Al Mamun², Asaduzzaman Shishir², \\ Marufa Zerin Aktar', Shakila Nargis Khan', Md. Mozammel Hoq ${ }^{2}$ and \\ Mohammad Shahnoor Hossain ${ }^{1}$
}

${ }^{1}$ Department of Genetic Engineering and Biotechnology, University of Dhaka, Dhaka-1000, Bangladesh

${ }^{2}$ Department of Microbiology, University of Dhaka, Dhaka-1000, Bangladesh

Received: May 28, 2015; Accepted: June 28; Published (Web): July 21, 2015

\begin{abstract}
Bacteriocins are ribosomally synthesized antibacterial peptides which have the potential to be used as natural food preservatives as well as alternative to antibiotics. Here, we report the production of bacteriocin-like inhibitory substances (BLIS) from the indigenous strains of Bacillus thuringiensis. Deferred antagonism bacteriocin assay and agar well diffusion methods suggested that several of the tested strains have high levels of bacteriocin-like activity against the common food-borne pathogens, Listeria monocytogenes, Staphylococcus aureus and Bacillus cereus. These bacteriocins are generally produced at the mid-logarithmic phase of growth with optimum temperature of 37 ${ }^{\circ} \mathrm{C}$, pH-7.0 and $24 \mathrm{~h}$ of incubation. Heat stability assay demonstrated that the bacteriocins produced from the strains are highly heat stable and can retain activity up to $100{ }^{\circ} \mathrm{C}$. Our study suggests that these bacteriocins may be potential candidates for use as biodegradable natural food preservatives and alternative antimicrobial agents to solve the increasing trends of problems of antibiotic resistance.
\end{abstract}

Key words: Bacteriocin, Bacillus thuringiensis, antimicrobial activity, Bangladeshi strains, food-borne pathogens

\section{Introduction}

Bacteriocins are ribosomally synthesized antimicrobial peptides or proteins which have the potential to inhibit other closely related bacteria, thereby imparting selective advantage to the producer bacteria in the natural environment (Hossain and Biswas 2011). However, the producer strain is immune to its own bacteriocin due to the presence of immunity protein (Hossain and Biswas, 2012). Broadly, bacteriocins can be classified into two major groups such as lantibiotics (which contains posttranslationally modified lanthionine groups) and nonlantibiotics (unmodified peptides) (Cotter et al., 2005). While most of the bacteriocins have very narrow spectrum of activity (active against the closely related species), some exhibit broad spectrum of activity (Nissen-Meyer et al., 2009).

Recently, the research on bacteriocins has received intense attention due to the escalating problems of antibiotic resistance among pathogenic bacteria and to control the food spoilage problems caused by undesirable microorganisms present in the food (Anthony et al., 2009). Bacteriocins from the Gram positive bacteria hold a great promise as an alternative to antibiotic in food, pharmaceutical and agriculture due to their high level of diversity (Jack et al., 1995; Kamoun et al., 2005; Rahman et al., 2015). Bacteriocins produced from the lactic acid bacteria have been extensively studied due to their GRAS (generally recognized as safe) status and several of them are being used widely in food industries such as nisin, pediocin etc. (Cotter et al., 2005). Most of the species of Bacillus, which have a history of safe use in food and industry, are also considered as an important source of bacteriocin (Pedersen et al., 2002). Several studies have suggested that strains from the genus of Bacillus produce a diverse array of bacteriocins which are active against various food-spoilage and pathogenic bacteria such as, subtilin (Jansen and Hirschmann, 1944; Zheng et al., 1999; Kindoli et al., 2012; Joseph et al., 2013) and subtilosin produced by B. subtilis (Zheng et al., 1999), cerein produced by $B$. cereus (Oscariz and Pisabarro,

Correspondence to: Mohammad Shahnoor Hossain; Phone: 8801554593702; Fax: 88029667222; Email: mshahnoor@ du.ac.bd 
2000), coagulin produced by B. coagulans (Hyronimus et al., 1998), megacin from B. megatorium (Kiss et al., 2008), licheniocin from B. licheniformis (He et al., 2006; Beric et al., 2013), and tochicin (Paik et al., 1997) and thauricin 7 (Cherif et al., 2001), thuricin 439 (Ahern et al., 2003), thauricin CD (Rea et al. 2010), entomocin (Cherif et al,. 2003), bacthuricin F4 (Kamoun et al., 2005) from B. thuringiensis.

In this study, we attempted to expand the search for novel bacteriocins produced by the renowned bacterium, B. thuringiensis, which is widely used in agriculture for the control of many insect pathogens. This bacterium is well-known for its ability to produce crystal protein (Cry, a $\delta$-endotoxin), which causes paralysis of the larval gut and cytolytic toxin (Cyt) (Aronson et al., 1986; Crickmore et al., 1998; Tounsi et al., 2003). As a result, most of the studies on B. thuringiensis have focused on its insecticidal activities and very little attention was given for other industrial products (Barboza-Corona et al., 2007). The main goal of the present study was to screen and characterize the novel bacteriocins from $B$. thuringiensis (Bt) isolated from different areas of Bangladesh (Asaduzzaman et al., 2012; Shishir et al., 2014). Here, we report that newly obtained bacteriocins are active against various pathogenic and food spoilage bacteria and are stable in a wide range of temperature and $\mathrm{pH}$.

\section{Materials and Methods}

Bacterial strains and culture conditions: 20 indigenous $B$. thuringiensis strains were obtained from the bacterial stock collection center at the Department of Microbiology, University of Dhaka. The strains were isolated from the soil sample of the various region of Bangladesh and identified by $16 \mathrm{~S}$ rDNA sequence analysis (Asaduzzaman et al., 2012; Shishir et al., 2014). The bacteria were routinely cultivated and screened for bacteriocin activity in tryptic soy agar or tryptic soy broth (HiMedia, India) at $30{ }^{\circ} \mathrm{C}$. Indicator bacteria (Table 1) were grown in the same tryptic soy medium at $37{ }^{\circ} \mathrm{C}$, except $L$. monocytogenes which was routinely cultivated in MRSA medium (Sigma, USA) and Streptococcus mutans which was cultivated in Todd-Hewitt medium (Sigma, USA).

Screening for bacteriocin activity: Initially, Bt strains were screened for antibacterial activity against the indicator bacteria on tryptic soy agar (TSA) using agar spot antibacterial assay. In brief, bacterial strains were spotted onto TSA plate and incubated overnight at $30{ }^{\circ} \mathrm{C}$ to form colonies. After the growth of producer strains on TSA plate, overnight grown indicator bacteria $\left(10^{9}\right.$ $\mathrm{CFU} / \mathrm{ml})$ were spread as soft agar $(0.5 \%)$ over the TSA plate and the cultures were grown for $24 \mathrm{~h}$ at $37{ }^{\circ} \mathrm{C}$. Antibacterial activity was determined by the presence of growth inhibition around the producer strains.

Bacteriocin production: $B t$ strains were grown in TSB for $20 \mathrm{~h}$ at $150 \mathrm{rpm}$ at $37^{\circ} \mathrm{C}$. After incubation, bacterial cells were separated by centrifugation at $6000 \mathrm{rpm}$ for 10 min and the supernatant was further sterilized by membrane filtration with $0.22 \mu \mathrm{m}$ membrane filter and stored at $-20{ }^{\circ} \mathrm{C}$ for further studies. Bacteriocin activity was determined out by agar well diffusion method (Jack et al., 1995). Briefly, $200 \mu \mathrm{l}$ of the overnight grown indicator bacteria $\left(10^{8} \mathrm{cfu} / \mathrm{ml}\right)$ were seeded onto the TSA plate and the well was constructed by a sterile borer. $30 \mu \mathrm{l}$ of the filter sterilized culture supernatant was loaded into the well and incubated overnight at $37{ }^{\circ} \mathrm{C}$. Bacteriocin activity was measured as zone of inhibition around the well. Each point of the activity was repeated for at least three times and the average was recorded. The bacteriocin activity was calculated as arbitrary unit (AU) as described by previously (Ahern et al., 2003) with some modification and determined as the multiplication of the diameter of inhibitory zones with highest dilution which produced visible growth inhibition.

Effect of temperature on the inhibitory activity of the Bt-BLIS: To investigate the thermostability of the BtBLIS, $100 \mu \mathrm{l}$ aliquots from the filtrated culture supernatants were incubated at a range of temperatures $\left(40,50,60,70,80,90\right.$ and $\left.100{ }^{\circ} \mathrm{C}\right)$ for $20 \mathrm{~min}$. After incubation, bacteriocin activity was performed as mentioned above and recorded as the zone of diameter in millimeters.

Mode of action: To determine the mode of action of the observed Bt-BLIS, $100 \mathrm{AU} / \mathrm{ml}$ of the bacteriocins were added to mid-logarithmic growth phase $\left(\mathrm{A}_{600}\right.$ of 0.40 ) of $S$. aureus cells in TSB medium and the culture was incubated at $37{ }^{\circ} \mathrm{C}$. TSB medium having bacterial cells without any bacteriocin was used as control experiment. Samples were taken at different time intervals 
and the viable cells were counted on TSA plates by the standard plate counting method.

\section{Results}

Screening of B. thuringiensis strains for antibacterial activity: A total of 20 indigenous $B t$ strains were screened for their antagonist activity against several common foodborne pathogens and food spoilage bacteria by agar spot antibacterial assay and well dilution method (Paik et al., 1997). Although most of the strains were able to display some extent of antibacterial activity against one or more indicator bacteria, while four isolates showed remarkable antimicrobial activities and were selected for further analysis (Table 1 and Figure 1a). Successive decrease in the zones of diameter with the increasing dilution of culture supernatant indicated that the observed antibacterial activity was not due to bacteriophage activity (Figure 1b). Culture supernatants from these four strains were sampled at different time intervals and assayed for bacteriocin activity. Based on the relation of growth kinetics and bacteriocin production, selected positive strains can be grouped into two categories (Figure 2). We included JeSa1 and Jsa3 in group I, which were able to produce the considerable level of antibacterial substance at mid logarithmic phase and reached maximum at the early stationary phase. $\mathrm{KkSc} 2$ and $34 \mathrm{~S}$ were included into group $B$ and the antibacterial activity started at the end of logarithmic phase and reached maximum at the middle of stationary phase. Interestingly, we observed a gradual decrease in bacteriocin activity after it reached the peak and lost the activity below detection level after $36 \mathrm{~h}$ of incubation.

Table 1. Spectrum of activity of Bt-BLIS. ' $U$ ' indicates the instability of the bacteriocin activity when incubated at $80{ }^{\circ} \mathrm{C}$ for 20 min.

\begin{tabular}{|c|c|c|c|c|c|c|}
\hline Indicator/Producer & $\begin{array}{l}\text { Bacillus } \\
\text { cereus }\end{array}$ & L. monocytogenes & $\begin{array}{c}\text { Staphylococcus } \\
\text { aureus }\end{array}$ & $\begin{array}{l}\text { S. mutans } \\
\text { UA159 }\end{array}$ & $\begin{array}{c}\text { Lactobacillus } \\
\text { sp. }\end{array}$ & $\begin{array}{l}\text { Bacillus } \\
\text { subtilis }\end{array}$ \\
\hline JeSa1 & ++ & +++ & +++ & + & - & - \\
\hline KfSa1 & - & - & - & - & - & - \\
\hline $\mathrm{KkSc} 2$ & - & $+++\mathrm{U}$ & $++\mathrm{U}$ & - & $+\mathrm{U}$ & $++\mathrm{U}$ \\
\hline Ssf1 & - & - & - & - & $+\mathrm{U}$ & - \\
\hline JSa1 & $+\mathrm{U}$ & - & - & - & $++\mathrm{U}$ & $++\mathrm{U}$ \\
\hline $\mathrm{JSa} 3$ & - & $++\mathrm{U}$ & $++\mathrm{U}$ & - & - & - \\
\hline Rpsa2 & - & - & - & - & - & - \\
\hline $\mathrm{JSb} 2$ & - & - & - & - & - & $++\mathrm{U}$ \\
\hline $15 \mathrm{~S}$ & - & - & $+\mathrm{U}$ & - & - & - \\
\hline $16 \mathrm{~S}$ & - & - & $+\mathrm{U}$ & - & - & - \\
\hline $20 \mathrm{~S}$ & - & $++\mathrm{U}$ & $+\mathrm{U}$ & - & - & - \\
\hline $26 \mathrm{~S}$ & - & $++\mathrm{U}$ & - & - & - & - \\
\hline $34 S$ & - & +++ & +++ & - & - & \\
\hline $37 \mathrm{~S}$ & - & - & $+\mathrm{U}$ & - & - & - \\
\hline $38 \mathrm{~S}$ & - & $+\mathrm{U}$ & - & - & - & - \\
\hline $40 \mathrm{~S}$ & - & ++ & ++ & - & - & - \\
\hline $41 \mathrm{~S}$ & - & ++ & ++ & - & - & - \\
\hline $42 \mathrm{~S}$ & - & - & - & - & - & - \\
\hline
\end{tabular}

Spectrum of inhibitory activity: To investigate the spectrum of inhibitory activity, Bt-BLIS preparations were tested against various indicator bacteria using the welldiffusion method (Table 1). Among the Gram-positive indicator bacteria, L. monocytogenes and S. aureus were prominently inhibited by the Bt-BLIS produced by most of the strains. JeSa1and Jsa1were able to inhibit the growth of B. cereus. JeSa1 was also able to inhibit the prominent dental pathogen, S. mutans. KkSc2, Jsa1 and Jsb2 displayed the inhibitory activity against $B$. subtilis and Lactobacillus sp. was inhibited by $\mathrm{KkSc} 2$, Ssf1 and Jsa1. None of the strains could inhibit the growth of any tested gram-negative bacteria. When Bt-BLIS were tested against other $B$. thuringiensis strains, bactericidal 
activities were observed against some of them also (data not shown).

Biochemical properties of the Bt-BLIS: To investigate the biochemical properties of the initially observed bacteriocins, partially purified Bt-BLIS were digested with various enzymes and incubated at various temperatures and $\mathrm{pH}$. The inhibitory activities of the all Bt-BLIS were lost when treated with proteinase $\mathrm{K}$, which indicates the peptide in nature of the observed bacteriocin (data not shown). Treatment with amylase, lipase, RNase didn't cause any inhibition of the bacteriocin activity (data not shown). When bacteriocin samples were incubated at various temperatures ranging from $40{ }^{\circ} \mathrm{C}$ to $100{ }^{\circ} \mathrm{C}$ for 20 min, most of the bacteriocin activities were lost. Only the bacteriocin from JeSa1, 34S, 40S and 41S could retain the activity at high temperature (Table 1). We considered them as heat stable, because they could retain the activity even at $100^{\circ} \mathrm{C}$ (Figure 3).

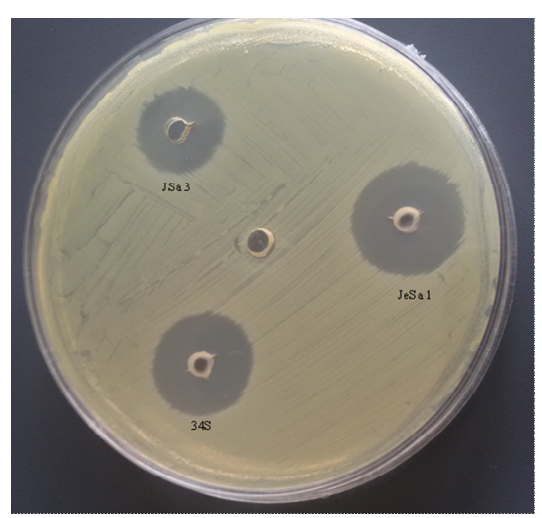

Figure 1(a)

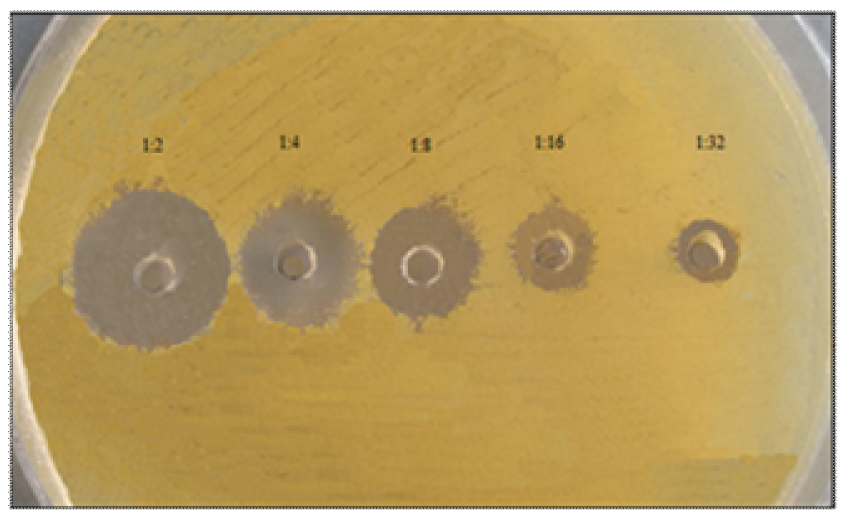

Figure 1(b)

Figure 1. Antagonistic activity of the $B t$ strains against $S$. aureus (1a) and activity at various dilutions of the filtrated culture supernatants against L. monocytogenes (1b). Indicator bacteria were grown overnight and adjusted to 0.5 McFarland turbidity standard and swabbed onto the TSA plate. Wells were made on the seeded plate with a sterile borer and $30 \mu 1$ of the filtrated culture supernatant was placed into the wells and incubated for overnight. After incubation, zones of inhibition around the wells were observed and measured as the millimeter in diameter. This plate is representative of at least three independent experiments.

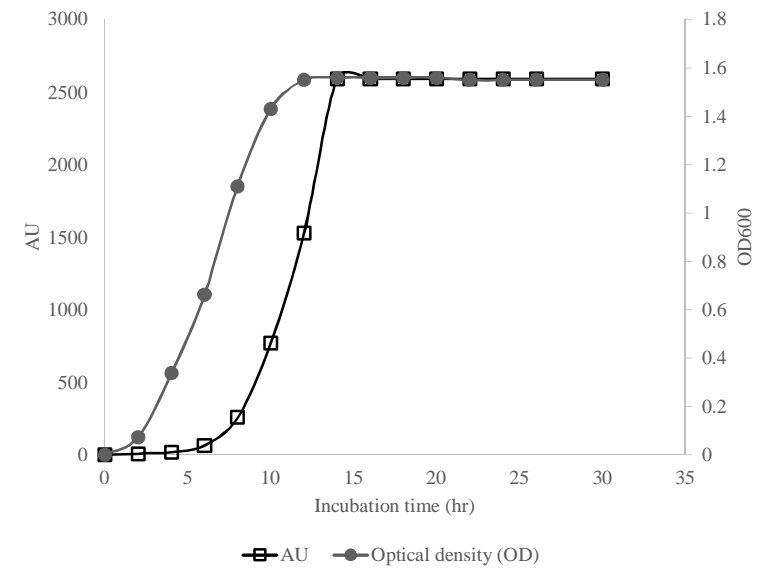

Figure 2(a)

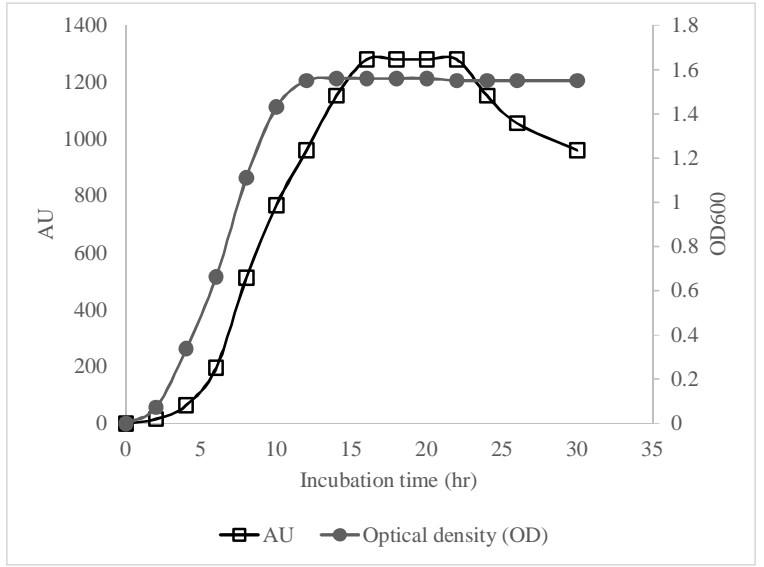

Figure 2(b)

Figure 2. Kinetics of bacteriocin production and the growth of B. thuringiensis. Bacteria were grown in tryptic soy broth and samples were collected in duplicate at $2 \mathrm{~h}$ intervals. One sample was used for antagonistic activity against $S$. aureus and the other was used for the measurement of optical density at $600 \mathrm{~nm}$. Each point represents the average of three independent experiments. Figure 2(a) represents the growth kinetics of JeSa1 and 2(b) represents the growth kinetics of 34S. Arbitrary unit (AU) is defined as the multiplication of diameter of inhibitory zones with the highest dilution which produced visible growth inhibition by the welldiffusion method. 


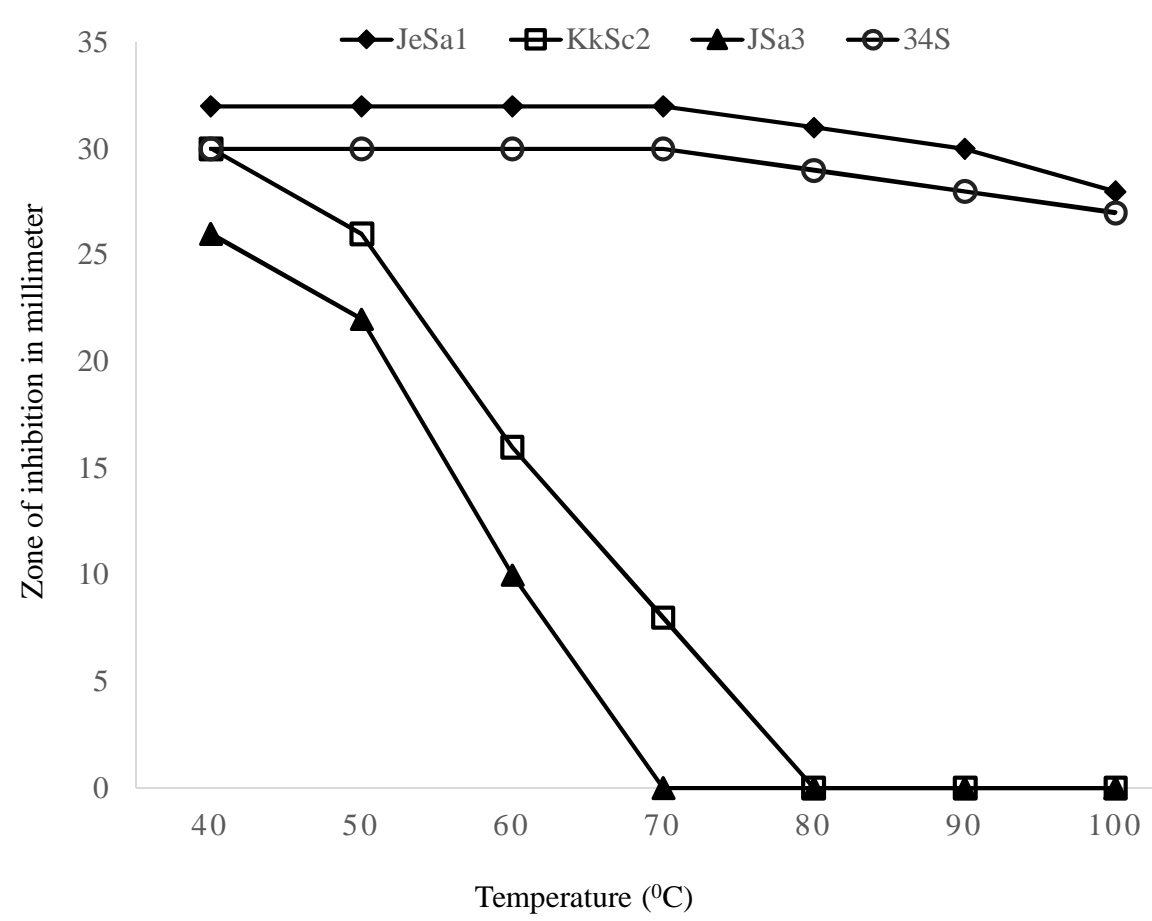

Figure 3. Effect of temperature on the activity of different Bt-BLIS. Filtrated culture supernatants were incubated at different temperatures for $20 \mathrm{~min}$ and assayed for growth inhibition against $L$. monocytogenes. Each point represents the average of at least three independent experiments.

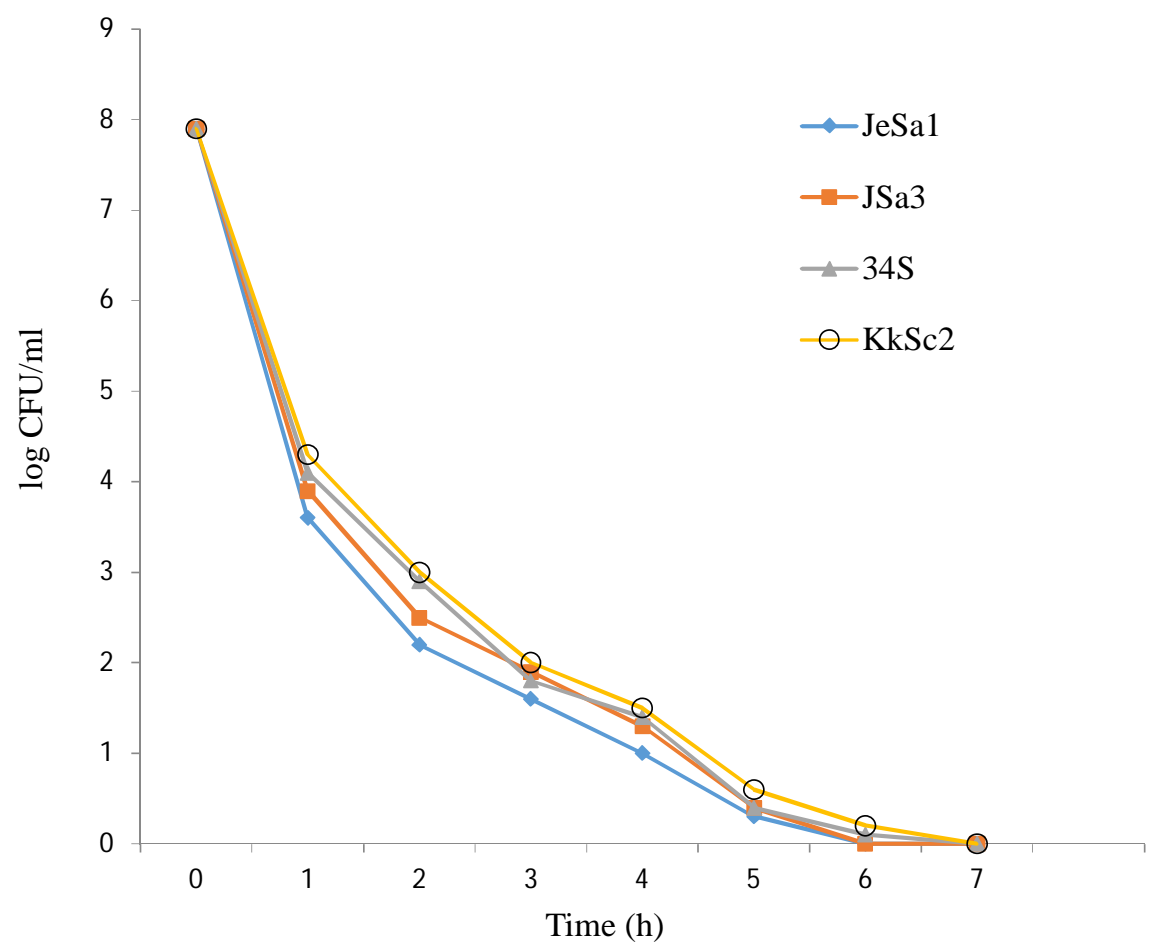

Figure 4. Mode of inhibition of the Bt-BLIS. $100 \mathrm{AU} / \mathrm{ml}$ of the bacteriocins were added to mid-logarithmic growth phase $\left(\mathrm{A}_{600}\right.$ of 0.40$)$ of $S$. aureus cells in TSB medium and the culture was incubated at $37^{\circ} \mathrm{C}$. Samples were taken at different time intervals and the viable cells were counted on TSA plates by standard plate counting method. Each point represents the average of at least three independent experiments. 
Mode of inhibition: In order to determine the mode of inhibition, exponentially growing indicator bacteria were incubated with $100 \mathrm{AU} / \mathrm{ml}$ of the bacteriocin and assessed for growth and viability. Our study revealed that the addition of bacteriocin caused a drastic decline in growth and viability within $1 \mathrm{~h}$ of incubation. A 100-fold reduction of viable cell number was observed within $1 \mathrm{~h}$ of growth and demonstrated total growth inhibition after 6 $\mathrm{h}$ (Figure 4). Our study indicated that the observed bacteriocin is bactericidal in nature.

\section{Discussion}

Increasing trends of health risks posed by the artificial preservatives in food products and the emergence of multi-drug resistant bacteria have raised the demand for the discovery of alternative natural products to alleviate these serious problems. Therefore, the scientific interest has been focused on the development of novel biodegradable preservatives for food products and the new antibacterial agents with pathogen specific activity. The aim of this study was to screen and characterize the novel bacteriocins from $B$. thuringiensis isolated from various areas of Bangladesh.

Among the 20 indigenous $B t$ strains, we found that 17 were able to exhibit bacteriocin-like inhibitory activities directed to the tested indicator bacteria. Based on growth kinetics, we have grouped these bacteriocins into two subgroups: group 1 includes the strains which were able to produce the considerable level of antibacterial substance at mid logarithmic phase and reached maximum at the early stationary phase and group II which includes the strains that producedthe maximum level of antibacterial activity at the middle of stationary phase. Our results are in consistent with two previous reports (Cherif et al., 2001; Barboza-Corona et al., 2007), where they reported that strains exhibited maximum bacteriocin-like activity at mid-logarithmic phase to middle of the stationary phase. Our studies also revealed that only four of the observed Bt-BLIS were heat stable, retaining the activity upto 100 ${ }^{\circ} \mathrm{C}$. Thuricin 7 and several other bactericions from $B t$ isolates were also reported to be stable at high temperature.

Among the indicator bacteria, Gram positive foodborne pathogens bacteria were prominently inhibited by the tested Bt-BLIS. Food-borne pathogens $L$. monocytogenes, $S$. aureus and B. cereus were inhibited by several Bt-BLIS. Cross activity assay among the $B t$ strains suggested that some of them are active against other $B t$ strains. In contrast with the bacteriocins of lactic acid bacteria, Bt-BLIS displayed relatively narrow spectrum of activity (Jack et al., 1995). Our findings suggested that some of these bacteriocins can be potentially used as food preservative to control food-borne pathogens. In the crossactivity assays performed in this study showed that bacteriocin from one $B t$ strain was able to inhibit the growth other $B t$ strains, which indicates the absence of immunity protein in the susceptible $B t$ strains.

Incubation time, temperature and $\mathrm{pH}$ play an important role bacteriocin production. (Kamoun et al., 2005; Barboza-Corona et al., 2007). Although the highest level of antibacterial activity was obtained when the culture was incubated at $37^{\circ} \mathrm{C}$, bacteriocin production was also observed from temperature 25 to $50{ }^{\circ} \mathrm{C}$ and activity diminished at $60^{\circ} \mathrm{C}$ (data not shown). Bacteriocin produced at alkaline $\mathrm{pH}$ is of particularly important as the $\mathrm{pH}$ of most of the food products are neutral to alkaline. BtBLIS from our producer strains are capable of producing bacteriocin at neutral to alkaline $\mathrm{pH}$ (data not shown). It has been reported that the nisin, widely used commercial food preservative, normally works at acidic $\mathrm{pH}$ and very unstable at alkaline condition (Liu and Hansen, 1990). Our result is in accordance with the bacteriocin, bacillocin 490 of $B$. licheniformis, which displayed antibacterial activity between acidic and alkaline pH (Martirani et al., 2002) .

Although they are able to produce entomocidal crystal protein (Aronson et al., 1986; Barboza-Corona et al., 2007), several studies have reported that $B$. thuringiensis is non-pathogenic and have excellent safety records (Siegel et al., 2001). As our purpose is to develop the protocol for the large scale production and purification of novel antimicrobial agents from $B t$ strains rather than the use of live bacterium, there will be no problem for their industrial use. As these bacteriocins are active against a lot of food-borne pathogens, they have the potential to be used as food preservative which will in turn contribute greatly to the food safety and food security issues thereby. Further studies to clone and identify the structural genes and the proteomics will help to unravel the nature of the 
peptides. In addition, the development of recombinant vectors for high-level expression will facilitate the large scale production and purification of these peptides for industrial use.

\section{Conclusions}

The current report is based on the screening, isolation and characterization of bacteriocins from local $B$. thuringiensis strains. Our studies revealed that the obtained Bt-BLIS can inhibit several common Gram positive food-borne pathogens. The results suggest that these Bt-BLIS can be used as alternative food preservatives in food industry and as therapeutic agents by the pharmaceutical industries. Further studies on purification, biochemical and genetic characterization are necessary to uncover the exact nature of these antibacterial agents.

\section{Acknowledgement}

We gratefully acknowledge the cooperation extended by Bioprocess Pilot Plant Laboratory, Center for Advance Research in Sciences (CARS), University of Dhaka during this study.

\section{Declaration of interests}

The authors declare that they have no conflict of interest.

\section{References}

Ahern, M. Verschueren, S. and van Sinderen, D. 2000. Isolation and characterisation of a novel bacteriocin produced by Bacillus thuringiensis strain B439. FEMS Microbiol. Lett. 220, 127-131.

Anthony, T., Rajesh, T., Kayalvizhi, N. and Gunasekaran, P. 2009. Influence of medium components and fermentation conditions on the production of bacteriocin(s) by Bacillus licheniformis AnBa9. Bioresour Technol. 100, 872-877.

Aronson, A.I., Beckman, W. and Dunn, P. 1986. Bacillus thuringiensis and related insect pathogens. Microbiol. Rev. 50, 1-24.

Asaduzzaman, M., Akter, A., Ilias, M., Khan, S.N. and Hoq, M.M. 2012. Characterization of locally isolated Bacillus thuringiensis for the development of eco-friendly biopesticides in Bangladesh. J. Biopesticide. 5, 216-222.

Barboza-Corona, J.E., Vazquez-Acosta, H., Bideshi, D. K. and Salcedo-Hernandez, R. 2007. Bacteriocin-like inhibitor substances produced by Mexican strains of Bacillus thuringiensis. Arch. Microbiol. 187, 117-126.

Beric, T., Stankovic, S., Draganic, V., Kojic, M., Lozo, J. and Fira, D. 2013. Novel antilisterial bacteriocin licheniocin 50.2 from Bacillus licheniformis VPS50.2 isolated from soil sample. J. Appl. Microbiol. 116,502-510.

Cherif, A., Chehimi, S., Limem, F., Hansen, B.M., Hendriksen, N.B., Daffonchio, D. and Boudabous, A. 2003. Detection and characterization of the novel bacteriocin entomocin 9 , and safety evaluation of its producer, Bacillus thuringiensis ssp. entomocidus HD9. J. Appl. Microbiol. 95, 990-1000.

Cherif, A., Ouzari, H., Daffonchio, D.H., Cherif, K., Ben Slama, A., Hassen, S. Jaoua and Boudabous A. 2001. Thuricin 7: a novel bacteriocin produced by Bacillus thuringiensis BMG1.7, a new strain isolated from soil. Lett. Appl. Microbiol. 32, 243-247.

Cotter, P.D., Hill, C. and Ross, R.P. 2005. Bacteriocins: developing innate immunity for food. Nat. Rev. Microbiol. 3, 777-788.

Crickmore, N., Zeigler, D.R., Feitelson, J., Schnepf, E., Van Rie, J.D., Lereclus, J. and Dean D.H. 1998. Revision of the nomenclature for the Bacillus thuringiensis pesticidal crystal proteins. Microbiol Mol. Biol. Rev. 62, 807-813.

He, L., Chen, W.Y.L. 2006. Production and partial characterization of bacteriocin-like pepitdes by Bacillus licheniformis ZJU1. Microbiol. Res. 161, 321-326.

Hossain, M.S. and Biswas, I. 2011. Mutacins from Streptococcus mutans UA159 are active against multiple streptococcal species. Appl. Environ. Microbiol. 77, 2428-2434.

Hossain, M.S. and Biswas, I. 2012. SMU.152 acts as an immunity protein for mutacin IV. J. Bacteriol. 194, 34863494.

Hyronimus, B., Le Marrec, C. and Urdaci, M.C. 1998. Coagulin, a bacteriocin-like inhibitory substance produced by Bacillus coagulans I4. J. Appl. Microbiol. 85, 42-50.

Jack, R.W., Tagg, J.R. and Ray, B. 1995. Bacteriocins of grampositive bacteria. Microbiol. Rev. 59, 171-200.

Jansen, E.F. and Hirschmann, D.J. 1944. Subtilin, an antibacterial product of Bacillus subtilis, culturing conditions and properties. Archives of Biochemistry. 4, 297 309.

Joseph, B., Dhas, B., Hena, V. and Raj, J. 2013. Bacteriocin from Bacillus subtilis as a novel drug against diabetic foot ulcer bacterial pathogens. Asian Pac. J. Trop. Biomed. 3, 942-946.

Kamoun, F., Mejdoub, H., Aouissaoui, H., Reinbolt, J., Hammami, A. and Jaoua, S. 2005. Purification, amino acid sequence and characterization of Bacthuricin F4, a new bacteriocin produced by Bacillus thuringiensis. J. Appl. Microbiol. 98, 881-888. 
Kindoli, S., Lee, H.A. and Kim, J.H. 2012. Properties of Bac W42, a bacteriocin produced by Bacillus subtilis W42 isolated from Cheonggukjang. J. Microbiol. Biotechnol. 22, 1092-1100.

Kiss, A., Baliko, G., Csorba, A., Chuluunbaatar, T., Medzihradszky, K.F. and Alfoldi, L. 2008. Cloning and characterization of the DNA region responsible for Megacin A-216 production in Bacillus megaterium 216. J. Bacteriol. 190, 6448-6457.

Liu, W. and Hansen, J.N. 1990. Some chemical and physical properties of nisin, a small-protein antibiotic produced by Lactococcus lactis. Appl. Environ. Microbiol. 56, 25512558.

Martirani, L., Varcamonti, M., Naclerio, G. and De Felice, M. 2002. Purification and partial characterization of bacillocin 490, a novel bacteriocin produced by a thermophilic strain of Bacillus licheniformis. Microb. Cell. Fact. 1, 1.

Nissen-Meyer, J., Rogne, P., Oppegard, C., Haugen, H.S. and Kristiansen, P.E. 2009. Structure-function relationships of the non-lanthionine-containing peptide (class II) bacteriocins produced by gram-positive bacteria. Curr. Pharm. Biotechnol.10, 19-37.

Oscariz, J.C. and Pisabarro, A.G. 2000. Characterization and mechanism of action of cerein 7, a bacteriocin produced by Bacillus cereus Bc7. J. Appl. Microbiol. 89, 361-369.

Paik, H.D., Bae, S.S., Park, S.H. and Pan, J.G. 1997. Identification and partial characterization of tochicin, a bacteriocin offduced by Bacillus thuringiensis subsp tochigiensis. J. Ind. Microbiol. Biotechnol. 19, 294-298.
Pedersen, P.B., Bjornvad, M.E., Rasmussen, M.D. and Petersen, J.N. 2002. Cytotoxic potential of industrial strains of Bacillus sp. Regul. Toxicol. Pharmacol. 36, 155-161.

Rahman, M., Islam, M.N., Islam, M.N. and Hossain, M.S. 2015. Isolation and identification of oral bacteria and characterization for bacteriocin production and antimicrobial sensitivity. Dhaka Univ. J. Pharm. Sci. 14, 103-109.

Rea, M.C., Sit, C.S., Clayton, E., O'Connor, P.M., Whittal, R.M., Zheng, J., Vederas, J.C., Ross, R.P. and Hill, C. 2010. Thuricin CD, a posttranslationally modified bacteriocin with a narrow spectrum of activity against Clostridium difficile. Proc. Natl. Acad. Sci. 107, 9352-9357.

Shishir, A., Roy, A., Islam N., Rahman, A., Khan S.N. and Hoq, M.M. 2014. Abundance and diversity of Bacillus thuringiensis in Bangladesh and their cry genes profile. Front. Environ. Sci. 2, 20.

Siegel, J.P. 2001. The mammalian safety of Bacillus thuringiensis-based insecticides. J. Invertebr. Pathol. 77, 13-21.

Tounsi, S., Zouari, N. and Jaoua, S. 2003. Cloning and study of the expression of a novel cryl Ia-type gene from Bacillus thuringiensis subsp. kurstaki. J. Appl. Microbiol. 95, 23-28.

Zheng, G., Yan, L.Z. Vederas, J.C. and Zuber, P. 1999. Genes of the sbo-alb locus of Bacillus subtilis are required for production of the antilisterial bacteriocin subtilosin. $J$. Bacteriol. 181, 7346-7355. 